\title{
Germination response to various temperature regimes of four Mediterranean seeder shrubs across a range of altitudes
}

\author{
Daniel Chamorro · Belén Luna · José M. Moreno
}

Received: 24 June 2013/Accepted: 26 September 2013

(C) Springer Science+Business Media Dordrecht 2013

\begin{abstract}
In dry-summer seasonal climates, the beginning of the rainy season can prompt germination under different temperatures, depending on altitude. Understanding germination responses to temperature with altitude is important in fire-prone environments for species regenerating after fire from seeds (seeders), particularly under changing climate. Here we investigated the role of temperature in four Mediterranean seeder shrubs from Central Spain. Seeds from 17 sites (285-1,253 m altitude), of two hard-seeded nanophanerophytes (Cistus ladanifer and C. salviifolius) and two soft-seeded chamaephytes (Lavandula pedunculata and Thymus mastichina) were investigated. Intact and heat shock treated seeds were set to germinate under four temperature regimes, including a treatment simulating future warming. GLM with binomial or gamma functions were used to test treatment effects using altitude as a covariate. Altitude was a significant covariate only in L. pedunculata. Temperature did not affect final germination in either Cistus, but it significantly affected $T$. mastichina, and interacted with
\end{abstract}

D. Chamorro · B. Luna · J. M. Moreno $(\square)$

Departamento de Ciencias Ambientales, Universidad de Castilla-La Mancha, Av. Carlos III s/n, 45071 Toledo, Spain

e-mail: Josem.Moreno@uclm.es

D. Chamorro

e-mail: Daniel.Chamorro@uclm.es

B. Luna

e-mail: Belen.Luna@uclm.es altitude in $L$. pedunculata, whereby the higher the altitude the less it germinated with decreasing temperature. Germination speed $\left(\mathrm{T}_{50}\right)$ was lower at colder temperatures in all but $C$. salviifolius that was insensitive to our treatments. Heat shock significantly increased final germination in both Cistus and $T$. mastichina, but did not interact with temperature or altitude. We conclude that germination response to temperature, including varying sensitivity with altitude, differed among these species; thus, changes in the timing of the onset of the rainy season will diversely affect populations at various altitudes. We discuss our results in a context of changing climate and fire.

Keywords Elevation gradient · Global warming · Niche breadth · Physical dormancy · Species range

\section{Introduction}

Temperature is perhaps the most important environmental factor controlling germination of imbibed seeds (Baskin and Baskin 1998; Probert 2000). Temperature and other environmental factors affecting germination vary along the distribution range of a species, and variations in germination responses along gradients of temperature or other factors have been documented (Meyer and Allen 1999; Donohue 2002). In seasonal climates with a dry and warm period, like 
Mediterranean-type areas, germination proceeds once suitable moisture conditions occur, most commonly following autumn rains and until spring (Keeley 1991; Espigares and Peco 1993; Bell et al. 1993; Quintana et al. 2004). The onset of the wet season is usually linked to frontal systems that depend on general circulation patterns; hence rain will fall throughout large areas. Thus, depending on altitude, germination will be prompted under different temperatures. Subsequent risks (i.e., soil surface drying or frost) are also related to altitude. Hence, provided that temperature can act as a germination controlling factor, a differential response to temperature along altitudinal gradients might be selected for. This has been documented in a number of studies in different environments and for various plant functional types (Cavieres and Arroyo 2001; Pendleton and Meyer 2004; Mondoni et al. 2008; Giménez-Benavides and Milla 2013). Verifying the relationship between germination response to temperature and altitude is important for understanding what factors control plant populations in seasonal climates with high year to year variability in the onset of the rainy season. Additionally, this is important in a context of global warming and changes in total precipitation and temporal patterns, as projected for a number of regions, including the Mediterranean (Christensen et al. 2007), which could shift the timing of the onset of the wet season.

Evidence of a relationship between germination sensitivity to temperature and altitude is neither general nor are the relationships of the same type. Some involve direct relationships to the germination process, while others are linked to changes in dormancy (i.e., chilling requirements). Furthermore, the relationship between germination sensitivity to temperature and altitude is not always the same. In some cases, studies have found an inverse relationship between germination response to temperature and altitude, whereby populations at higher altitudes show highest germination at warmer temperatures, while those at low altitudes show highest germination at lower temperatures (Thurling 1966; Smith 1975; Gilfedder and Kirkpatrick 1994). In some studies, changes in hormones or other compounds have been associated to this relationship (Angosto and Matilla 1993; Matilla et al. 2005). Other studies found the opposite response pattern, by which species at high altitudes germinate best at lower temperatures and those at low altitudes germinate best at warmer temperatures (Mariko et al. 1993; Cochrane et al. 2011). The ecological implications of a given relationship in the context of climate change will be different. Whereas greater germination at higher temperatures in high altitude sites would favor the upward movement of a species with elevated temperature, greater germination at lower temperature and altitude would hinder it.

The sensitivity of a species to changes in the temperature of the germination environment will depend on its germination temperature niche. Niche position, that is, temperature at which the optimum germination takes place, and niche breadth, that is, the range of temperatures within which most germination occurs, are both important (Luna and Moreno 2010). Mediterranean species are acknowledged to have an optimum germination at relatively low temperatures (Thompson 1970; McArthur et al. 1987; Bell et al. 1993), which is consistent with their more frequent germination from autumn to spring (Ortega et al. 1997; Céspedes et al. 2012). Germinability is commonly greatest between 15 and $20{ }^{\circ} \mathrm{C}$, decreasing markedly above $20{ }^{\circ} \mathrm{C}$ (Thanos and Georghiou 1988; Pérez-García and González-Benito 2006; Luna et al. 2012). Germination temperature niche breadth is also highly variable among species; while some species have a narrow range of temperature requirements, others exhibit similar germination when tested across a range of temperatures (Galmés et al. 2006; Luna et al. 2012). Highest risk to changes in climate would be anticipated for species with reduced niche breadth and distribution range, while those with broader niche breadth and distribution range would be less vulnerable (Luna and Moreno 2010).

The aim of this study was to determine how seed germination varies with altitude in four Mediterranean woody shrub species set to germinate under varying temperature regimes. To investigate this, seeds of four species, two without dormancy and two with physical dormancy, were collected in seventeen sites along the Iberian Central Range, ranging from 285 to $1,253 \mathrm{~m}$ a.s.l. Seeds were set to germinate in chambers simulating four day/night alternating temperature regimes. Temperature treatments simulated current and future autumn conditions expected under additional global warming. Because Mediterranean shrublands burn frequently, a further objective was to evaluate the interaction between germinating temperature and heat exposure as in fire. The questions 
addressed were, to what extent is the germination of four shrubs, some endemic to the Western part of the Mediterranean, sensitive to the temperature of the germinating environment? Does this sensitivity vary among populations that differ in altitude? In case it does, does a heat shock affect this relationship? Our study would help better understand how shifts in rainfall, which are common from year to year in Mediterranean environments, could affect species that recruit from seeds (i.e., seeders) in burned areas. Under these circumstances, variations in the timing of germination can affect recruitment (Moreno et al. 2011), and fitness in general (De Luis et al. 2008), to the extent that survival, among other processes, may be linked to the time of germination. Additionally, we aimed at better understanding how changes in climate, by affecting temperatures, and shifting precipitations patterns, could affect these widespread species in the Western Mediterranean.

\section{Methods}

Species collection and sites

The species selected were Cistus ladanifer L., C. salviifolius L. (Cistaceae) (nanophanerophytes), Lavandula pedunculata (Mill.) Cav., and Thymus mastichina (L.) L. (Lamiaceae) (chamaephytes). Except $C$. salviifolius that is distributed throughout the Mediterranean the other species are distributed in the Western Mediterranean, mainly in the Iberian Peninsula and parts of Northern Morocco. The species are abundant in abandoned areas, forming extensive shrublands that are now affected by wildfires. The four species rely on recruitment from seeds for population maintenance after fire, and are classified as seeders, that is, they do not resprout after fire. Nonetheless, seed characteristics of the two families are different. Cistaceae have seeds with a hard, impermeable coat (i.e., they have physical dormancy) (Baskin and Baskin 2000), their scarification being promoted by exposure to heat as in fire (Thanos et al. 1992). On the contrary, Lamiaceae have soft coats and imbibe after being moistened, and most seeds germinate readily without requiring a heat shock (Thanos and Doussi 1995; Pérez-García et al. 2003).

Seventeen sites were selected along a $150 \times 80 \mathrm{~km}$ rectangle following the Central Range of the Iberian Peninsula (from Sierra de Gredos to Sierra de Guadarrama, Central Spain). The sites were chosen to represent the range of altitudes of these species across this part of Iberia, covering a range of ca. $1,000 \mathrm{~m}$ in altitude (from $285 \mathrm{~m}$ to $1,253 \mathrm{~m}$ a.s.l.). C. salviifolius is not very abundant above $1,000 \mathrm{~m}$, which forced us to select sites only up to $831 \mathrm{~m}$ for this species. Precipitation in the study area is concentrated from autumn (October being the first wet season month) to spring. Based on the Digital Climatic Atlas of the Iberian Peninsula (Ninyerola et al. 2005) we estimated that the mean maximum temperature in October at the lowest site was $23{ }^{\circ} \mathrm{C}$, and at the highest site $17^{\circ} \mathrm{C}$. Similarly, mean minimum temperature for October at the lowest site was $10{ }^{\circ} \mathrm{C}$, while at the highest site was $5{ }^{\circ} \mathrm{C}$.

Mature fruits of each species were harvested from 10 individuals at each site in summer, at the time of natural dispersal (Table 1). In the laboratory, seeds were removed from the fruits and cleaned. In the case of the Lamiaceae, the nucule was used as the germinating unit. Seeds were kept in paper bags at room temperature until treated.

\section{Germination experiment}

Prior to germination, half of the seeds were exposed to a heat shock treatment $\left(90{ }^{\circ} \mathrm{C}\right.$ for $\left.10 \mathrm{~min}\right)$ simulating the heating that occurs at the soil surface during shrubland fires (Moreno et al. 2011; Céspedes et al. 2012). Seeds were set at four different temperature regimes with a photoperiod of $12 / 12 \mathrm{~h}: 1$ ) $14 / 4{ }^{\circ} \mathrm{C}$; 2 ) $18 / 8{ }^{\circ} \mathrm{C}$; 3) $22 / 12{ }^{\circ} \mathrm{C}$; and 4) $26 / 16{ }^{\circ} \mathrm{C}$. The first three temperature regimes covered the range of day and night temperatures registered in October from the highest to the lowest site (Table 1). The warmest temperature treatment would simulate temperature conditions compatible with projected regional warming. By the end of the century, in the center of the Iberian Peninsula mean maximum/minimum temperatures in fall are projected to increase $4.4 / 3.8{ }^{\circ} \mathrm{C}$ for the A1B emission scenario (Agencia Estatal de Meteorología, Regionalización dinámica ENSEMBLES: www.aemet.es).

Seeds were set to germinate in Petri dishes $(5.5 \mathrm{~cm}$ in diameter) over two sheets of filter paper (Whatman no. 1). Six Petri dishes, each with 25 seeds, were used per species and site and for each incubation temperature treatment for each unheated and heated seeds. 
Table 1 Geographic coordinates, altitude (Alt), mean annual precipitation (Pre), mean annual temperature (T), mean maximum/ minimum temperature of October $\left(T_{\mathrm{O}}\right)$ and species harvested at each site

\begin{tabular}{|c|c|c|c|c|c|c|c|c|c|c|c|}
\hline \multicolumn{2}{|c|}{ Latitude $(\mathrm{N})$} & \multicolumn{2}{|c|}{ Longitude (W) } & \multirow{2}{*}{$\frac{\text { Alt }(\mathrm{m})}{285}$} & \multirow{2}{*}{$\frac{\text { Pre }(\mathrm{mm})}{839}$} & \multirow{2}{*}{$\frac{T\left({ }^{\circ} \mathrm{C}\right)}{15}$} & \multirow{2}{*}{$\frac{\text { To }\left({ }^{\circ} \mathrm{C}\right)}{23 / 10}$} & \multirow{2}{*}{$\frac{C l}{\mathrm{X}}$} & \multirow{2}{*}{$\frac{C s}{\mathrm{X}}$} & \multirow{2}{*}{$\frac{L p}{\mathrm{X}}$} & \multirow{2}{*}{$\frac{T m}{\mathrm{X}}$} \\
\hline $40^{\circ}$ & $5.17^{\prime}$ & $5^{\circ}$ & $24.57^{\prime}$ & & & & & & & & \\
\hline $40^{\circ}$ & $7.02^{\prime}$ & $5^{\circ}$ & $17.63^{\prime}$ & 342 & 915 & 15 & $23 / 10$ & $\mathrm{X}$ & $\mathrm{X}$ & $\mathrm{X}$ & $\mathrm{X}$ \\
\hline $40^{\circ}$ & $2.79^{\prime}$ & $5^{\circ}$ & $2.25^{\prime}$ & 376 & 839 & 15 & $23 / 10$ & $\mathrm{X}$ & $\mathrm{X}$ & $\mathrm{X}$ & $\mathrm{X}$ \\
\hline $40^{\circ}$ & $20.66^{\prime}$ & $4^{\circ}$ & $12.30^{\prime}$ & 545 & 607 & 16 & $20 / 12$ & $\mathrm{X}$ & & $\mathrm{X}$ & $\mathrm{X}$ \\
\hline $40^{\circ}$ & $13.84^{\prime}$ & $3^{\circ}$ & $55.67^{\prime}$ & 570 & 540 & 14 & $21 / 10$ & $\mathrm{X}$ & $\mathrm{X}$ & $\mathrm{X}$ & $\mathrm{X}$ \\
\hline $40^{\circ}$ & $19.71^{\prime}$ & $4^{\circ}$ & $4.61^{\prime}$ & 607 & 466 & 15 & $20 / 9$ & $\mathrm{X}$ & & $\mathrm{X}$ & \\
\hline $40^{\circ}$ & $10.42^{\prime}$ & $3^{\circ}$ & $33.13^{\prime}$ & 620 & 437 & 14 & $21 / 8$ & & $\mathrm{X}$ & $\mathrm{X}$ & $\mathrm{X}$ \\
\hline $40^{\circ}$ & $10.24^{\prime}$ & $5^{\circ}$ & $24.79^{\prime}$ & 654 & 903 & 14 & $21 / 10$ & $\mathrm{X}$ & $\mathrm{X}$ & $\mathrm{X}$ & $\mathrm{X}$ \\
\hline $40^{\circ}$ & $11.05^{\prime}$ & $5^{\circ}$ & $20.05^{\prime}$ & 800 & 1,043 & 12 & $19 / 6$ & $\mathrm{X}$ & $\mathrm{X}$ & $\mathrm{X}$ & $\mathrm{X}$ \\
\hline $40^{\circ}$ & $42.57^{\prime}$ & $3^{\circ}$ & $36.11^{\prime}$ & 815 & 534 & 13 & $19 / 8$ & & $\mathrm{X}$ & & \\
\hline $40^{\circ}$ & $47.41^{\prime}$ & $3^{\circ}$ & $34.11^{\prime}$ & 831 & 544 & 13 & $19 / 7$ & & $\mathrm{X}$ & & \\
\hline $40^{\circ}$ & $7.16^{\prime}$ & $4^{\circ}$ & $43.79^{\prime}$ & 879 & 889 & 13 & $19 / 7$ & & $X$ & & \\
\hline $40^{\circ}$ & $53.63^{\prime}$ & $3^{\circ}$ & $29.72^{\prime}$ & 1,081 & 484 & 12 & $18 / 8$ & & & $X$ & $\mathrm{X}$ \\
\hline $40^{\circ}$ & $52.57^{\prime}$ & $3^{\circ}$ & $36.48^{\prime}$ & 1,131 & 633 & 11 & $17 / 6$ & $\mathrm{X}$ & & $X$ & $X$ \\
\hline $40^{\circ}$ & $8.66^{\prime}$ & $4^{\circ}$ & $42.77^{\prime}$ & 1,154 & 844 & 11 & $18 / 6$ & $X$ & & $X$ & $\mathrm{X}$ \\
\hline $40^{\circ}$ & $44.73^{\prime}$ & $3^{\circ}$ & $52.00^{\prime}$ & 1,200 & 654 & 12 & $18 / 6$ & $X$ & & $X$ & $X$ \\
\hline $40^{\circ}$ & $52.50^{\prime}$ & $3^{\circ}$ & $52.50^{\prime}$ & 1,253 & 679 & 11 & $17 / 5$ & $\mathrm{X}$ & & $\mathrm{X}$ & \\
\hline
\end{tabular}

Climate data from Atlas Climático de la Península Ibérica (Ninyerola et al. 2005)

$\mathrm{Cl}$, Cistus ladanifer; Cs, Cistus salviifolius; Lp, Lavandula pedunculata; Tm, Thymus mastichina

All Petri dishes were sealed with parafilm to prevent them from desiccating. Filter papers were kept soaked during the whole experiment. Dishes were laid at random on temperature controlled chambers (Model G-21, Ibercex). Every three days, germination was scored, and all germinated seeds were removed. Radicle emergence was the criterion used for scoring a seed as germinated. After each count, the position of each dish was changed to avoid chamber position effect. The experiment lasted 60 days, and at the end of this period, the viability of the non-germinated seeds was checked by means of the tetrazolium chloride test. Testing was made after the seeds were cut in two halves and incubated in a $1 \%$ solution of 2,3,5-triphenyl tetrazolium chloride for $48 \mathrm{~h}$ in dark conditions (International Seed Testing Association 1999). Final germination data were corrected by viability.

Data analysis

The germination process was characterized by the final germination percentage (FG) at the end of the experiment, and by germination speed, using the number of days required to reach $50 \%$ of the total germination $\left(\mathrm{T}_{50}\right)$. Generalized linear models with maximum likelihood for $\mathrm{FG}$ and $\mathrm{T}_{50}$ were fitted to test differences across treatments and in relation to altitude. Based on error structure we assumed a binomial error distribution for FG, and a gamma error distribution for $\mathrm{T}_{50}$. Different link functions were fitted, and according to Akaike's Information Criteria (Akaike 1992) the best fit for FG was a logit link whereas for $\mathrm{T}_{50}$ a log function. Each species was tested for the effects of temperature (four levels, each corresponding to the four temperature regimes) and heat shock (two levels, unheated and heated) as fixed factors with altitude (continuous variable) being a covariate. When temperature treatment effects were significant, pairwise comparisons among treatments were performed using Bonferroni correction. For those species in which altitude was not significant $(P \geq 0.05)$, the covariate was not further included in the models. When this covariate was significant, logit regressions were carried out to explore the relationship between the relevant germination variable and altitude for each temperature treatment. In this case, if heat shock effects were not significant, data from heated 
Fig. 1 Final germination (in \%) and germination speed ( $\mathrm{T}_{50}$ in days) for each temperature treatment. Mean and standard errors are presented for unheated $(-\mathrm{H})$ and heated seeds $(+\mathrm{H})$; in the case of $L$. pedunculata, data are corrected for covariatealtitude. Different letters show significant differences among temperature treatments from pairwise comparisons with Bonferroni correction $(P<0.05)$ after GLM analysis (see Table 2)
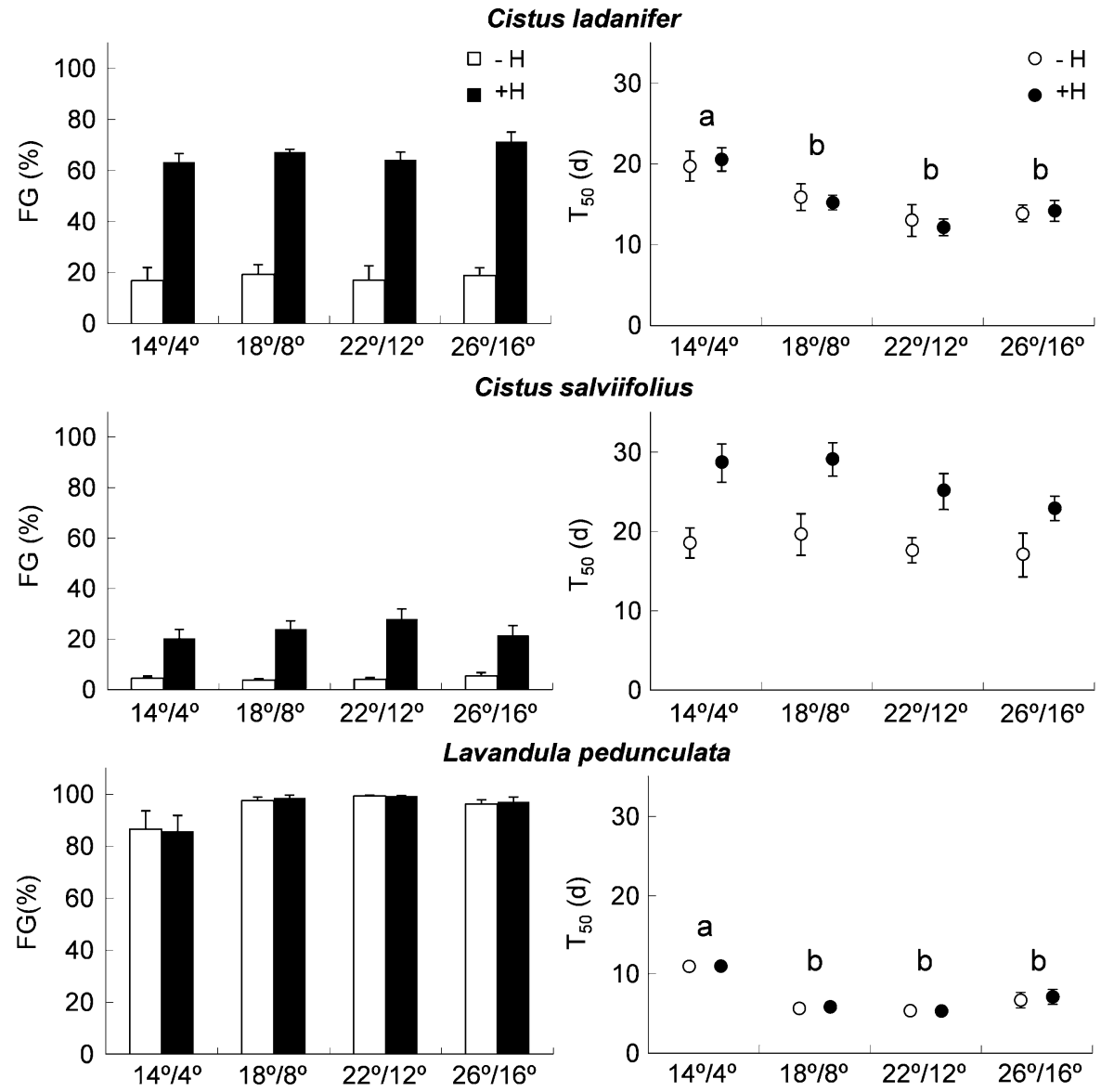

Thymus mastichina
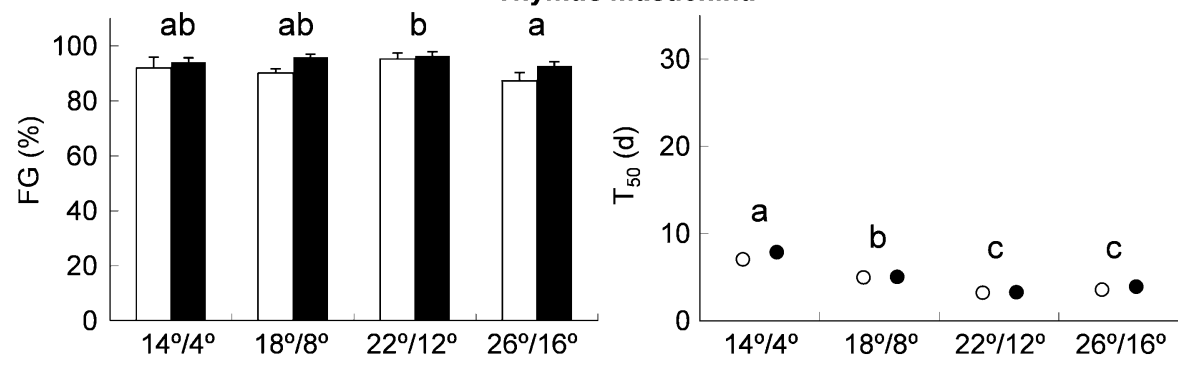

and unheated treatments were lumped together. All statistical analyses were completed using the SPSS Statistic version 19.0 (SPSS, Chicago, IL, USA).

\section{Results}

Germination was very variable among the four species; the two Cistaceae produced lower values than both Lamiaceae, which, in some cases, practically reached near full germination (Fig. 1). Altitude was not significantly related to any of the two germination variables or interacted with either heat shock or temperature treatments in any of the species except in the case of final germination in L. pedunculata (Table 2). Thus, only in this case was this variable retained in further analyses.

Temperature treatment differentially affected final germination and/or germination speed in some species (Table 2; Fig. 1). Final germination of both Cistus was 
Table 2 Results from GLM for altitude (A), heat shock (H), and temperature $(\mathrm{T})$ effects on final germination proportion (FG) and germination speed $\left(\mathrm{T}_{50}\right)$

\begin{tabular}{|c|c|c|c|c|c|c|}
\hline & \multicolumn{3}{|l|}{ FG } & \multicolumn{3}{|l|}{$\mathrm{T}_{50}$} \\
\hline & $\bar{\chi}^{2}$ & $\mathrm{df}$ & $P$ & $\overline{\chi^{2}}$ & $\mathrm{df}$ & $P$ \\
\hline \multicolumn{7}{|l|}{ C. ladanifer } \\
\hline Altitude & 1.503 & 1 & 0.220 & 3.219 & 1 & 0.073 \\
\hline Heat & 205.787 & 1 & $<0.001$ & 0.008 & 1 & 0.929 \\
\hline Temperature & 1.714 & 3 & 0.634 & 26.525 & 3 & $<0.001$ \\
\hline $\mathrm{A}^{*} \mathrm{H}$ & - & - & - & - & - & - \\
\hline $\mathrm{A}^{* \mathrm{~T}}$ & - & - & - & - & - & - \\
\hline $\mathrm{H}^{* \mathrm{~T}}$ & 0.425 & 3 & 0.935 & 0.465 & 3 & 0.926 \\
\hline $\mathrm{A} * \mathrm{H} * \mathrm{~T}$ & - & - & - & - & - & - \\
\hline \multicolumn{7}{|l|}{ C. salviifolius } \\
\hline Altitude & 0.372 & 1 & 0.542 & 3.231 & 1 & 0.072 \\
\hline Heat & 96.374 & 1 & $<0.001$ & 25.930 & 1 & $<0.001$ \\
\hline Temperature & 0.607 & 3 & 0.895 & 4.320 & 3 & 0.229 \\
\hline $\mathrm{A}^{*} \mathrm{H}$ & - & - & - & - & - & - \\
\hline $\mathrm{A}^{* \mathrm{~T}}$ & - & - & - & - & - & - \\
\hline $\mathrm{H}^{*} \mathrm{~T}$ & 1.699 & 3 & 0.637 & 0.484 & 3 & 0.922 \\
\hline $\mathrm{A} * \mathrm{H}^{*} \mathrm{~T}$ & - & - & - & - & - & - \\
\hline \multicolumn{7}{|l|}{ L. pedunculata } \\
\hline Altitude & 11.028 & 1 & 0.001 & 0.149 & 1 & 0.700 \\
\hline Heat & 0.004 & 1 & 0.951 & 0.069 & 1 & 0.792 \\
\hline Temperature & 4.273 & 3 & 0.233 & 114.586 & 3 & $<0.001$ \\
\hline $\mathrm{A} * \mathrm{H}$ & 0.016 & 1 & 0.901 & - & - & - \\
\hline $\mathrm{A}^{*} \mathrm{~T}$ & 10.593 & 3 & 0.014 & - & - & - \\
\hline $\mathrm{H}^{*} \mathrm{~T}$ & 0.628 & 3 & 0.890 & 0.209 & 3 & 0.976 \\
\hline $\mathrm{A} * \mathrm{H} * \mathrm{~T}$ & 0.546 & 3 & 0.909 & - & - & - \\
\hline \multicolumn{7}{|l|}{ T. mastichina } \\
\hline Altitude & 0.358 & 1 & 0.550 & 0.840 & 1 & 0.359 \\
\hline Heat & 5.844 & 1 & 0.016 & 1.644 & 1 & 0.200 \\
\hline Temperature & 22.646 & 3 & $<0.001$ & 157.147 & 3 & $<0.001$ \\
\hline $\mathrm{A} * \mathrm{H}$ & - & - & - & - & - & - \\
\hline $\mathrm{A}^{*} \mathrm{~T}$ & - & - & - & - & - & - \\
\hline $\mathrm{H}^{*} \mathrm{~T}$ & 1.052 & 3 & 0.789 & 0.850 & 3 & 0.837 \\
\hline $\mathrm{A} * \mathrm{H}^{*} \mathrm{~T}$ & - & - & - & - & - & - \\
\hline
\end{tabular}

When the covariate-altitude was not significant $(P \geq 0.05)$, it was not further included in the model $(-)$. Significant $P$ values are marked in bold

not affected by temperature treatments, but germination speed in one species (C. ladanifer) was significantly affected, whereby germination speed was lowest at the coldest treatment, with no differences among the three warmer treatments. In L. pedunculata,
Table 3 Logit regressions for the effects of altitude on each temperature treatment for $L$. pedunculata

\begin{tabular}{lllllr}
\hline Treatment & Intercept & $\beta$ & df & \multicolumn{1}{l}{$\mathrm{N}$} & \multicolumn{1}{l}{$P$} \\
\hline $14^{\circ} / 4^{\circ}$ & 4.563 & -0.0036 & 1 & 28 & $<\mathbf{0 . 0 0 1}$ \\
$18^{\circ} / 8^{\circ}$ & 6.268 & -0.0031 & 1 & 28 & $<\mathbf{0 . 0 0 1}$ \\
$22^{\circ} / 12^{\circ}$ & 6.260 & -0.0017 & 1 & 28 & $\mathbf{0 . 0 0 7}$ \\
$26^{\circ} / 16^{\circ}$ & 3.509 & -0.0002 & 1 & 28 & 0.525 \\
\hline
\end{tabular}

Significant $P$ values are marked in bold

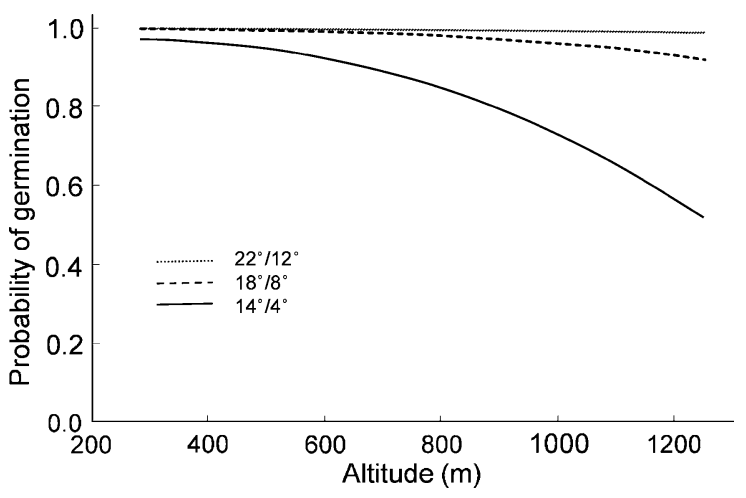

Fig. 2 Logit regression showing probability of germination with altitude for the temperature treatments in which the relationship between germination and altitude was significant (see Table 3)

after correcting for altitude, main effects of temperature treatments on final germination were not significant, but the interaction between altitude and temperature treatments was (Table 2). The effect of altitude on final germination in this species was negative (i.e., germination decreased with altitude), and varied depending on temperature (Table 3; Fig. 2). Thus, germination of seeds from higher altitudes was lower than that of seeds from lower altitudes, the effect being greater the colder the temperature treatment. The effect of altitude was significant in the three colder temperature treatments, not so in the warmest one (Table 3). Final germination in T. mastichina was significantly affected by temperature treatments (Fig. 1). The sensitivity to temperature was not very great, there being no statistically significant differences between the first three colder treatments, or between the first two colder and the warmest treatments. The only significant change occurred between the two warmest treatments with a decrease in final germination at the highest temperature treatment (Fig. 1). In both Lamiaceae, 
germination speed $\left(\mathrm{T}_{50}\right)$ was significantly affected by the temperature treatments and this effect was not related to altitude in either case. In T. mastichina, $\mathrm{T}_{50}$ was highest at the coldest treatment, decreasing as temperatures increased for the first three colder treatments, remaining unchanged as temperatures further increased. In the case of $L$. pedunculata, the effect of increasing temperature on $\mathrm{T}_{50}$ was only significantly decreased from the coldest to the next warmer treatment, followed by no change as temperatures further increased.

Exposing the seeds to a heat shock significantly increased germination in both Cistus (by a factor of 4-6), and in T. mastichina (factor of 1.05), but not in $L$. pedunculata (Fig. 1; Table 1). Thus, C. ladanifer increased its final germination from a mean of 18 to $66 \%, C$. salviifolius from a mean of 4 to $23 \%$ and $T$. mastichina from a mean of 89 to $94 \%$. Heat shock did not significantly affect germination speed $\left(\mathrm{T}_{50}\right)$, except in C. salviifolius, in which case germination speed was slower in the heated seeds, the $T_{50}$ increasing from a mean of 18 days to a mean of 26 days. As indicated, heat shock did not interact with temperature or altitude.

\section{Discussion}

Altitude was a significant factor for final germination in only one species (L. pedunculata), showing a significant interaction with temperature, but not in the other three species tested. Our results contrast with earlier works that found that final germination was uncorrelated with altitude in Lavandula stoechas (a closely related species to L. pedunculata) and negatively correlated in T. mastichina (Pérez-García et al. 2003). However, in that study, only one temperature was tested. As for hard-seeded species, our results also contrast with studies that found a significant relationship between final germination percentage and altitude (Angosto and Matilla 1993), although the species investigated by these authors were Leguminosae, not Cistaceae, and no heat shock was involved. Studies with both Lamiaceae and Cistus species had shown that final germination can differ among populations from different provenances, although it has not been determined whether habitat correlates or other factors, including genetic variability, were behind these findings (Pérez-García 1997; Pérez-García et al. 2003;
Moreira et al. 2012). The high significance of altitude as a covariate and of the interaction between this and final germination response to temperature in $L$. pedunculata suggest that temperature habitat characteristics were responsible for the results found for this species.

Additionally, this work also documents that the germination sensitivity to temperature varied among the four species investigated, irrespective of altitude. In general, the mean optimum germination temperature for shrubs from sclerophyllous woodland is $19{ }^{\circ} \mathrm{C}$ (Baskin and Baskin 1998). Research with Cistus species have reported decreased germination at constant temperatures of $25{ }^{\circ} \mathrm{C}$ (Thanos and Georghiou 1988; Corral et al. 1990) and at fluctuating temperatures lower $\left(25 / 15{ }^{\circ} \mathrm{C}\right)$ than the warmest treatment used here (Galmés et al. 2006). In the present work, both Cistus were not significantly affected by the four temperature regimes tested in the final germination and only one (C. ladanifer) was affected in germination speed. Therefore, it seems that the two Cistus species have a relatively large germination temperature niche breadth, and there is little variability in total germination or speed (more so in C. salviifolius than in C. ladanifer for the latter) within a large range of temperatures. We suggest that germination in these two species is not very sensitive to year to year variations in the onset of the rainy season after the summer dry season. This is true at the altitudes investigated, but it probably applies throughout their range, particularly towards lower elevations, since our treatments covered a large range of temperatures, although towards the warmer side. Similarly, it can be contended that these two species will be little sensitive to changes in temperature due to regional warming, since the only significant difference detected in one of the species was between the coldest and next warmer temperature treatment, not between the three warmer ones. Changes in rainfall temporal patterns in a warmer climate that project a delay in the onset of the rainy season (Giorgi and Lionello 2008) would probably not alter this.

On the other hand, germination of the two Lamiaceae was somewhat sensitive to the range of temperatures used in this experiment and for either final germination ( $T$. mastichina) or germination speed (both species). Decreased final germination at high $\left(25^{\circ} \mathrm{C}\right)$ and low $\left(5^{\circ} \mathrm{C}\right)$ constant temperature has been documented in other Lamiaceae (Thanos et al. 1995; 
Kadis et al. 2010), although these works were done using constant temperatures, and it has been shown that germination is often enhanced by alternating temperatures (Fenner and Thompson 2005), as done here. Additionally, we found that their response to the various temperature regimes was not the same. Reduction in final germination of T. mastichina was only between the two warmest temperature treatments, confirming some sensitivity to high temperatures (Luna et al. 2012). On the other hand, the germination sensitivity to temperature of $L$. pedunculata changed with altitude. The final germination of $L$. pedunculata was less sensitive to warmer temperatures, and this was true across the altitudinal range studied, but was sensitive to colder temperatures, with a significant decreased in germination as altitude increased. Reduced sensitivity in this species to warm temperatures has been documented earlier (Fuentes-Molina and Estrelles 2005). These responses indicate that the germination temperature niche breadth in these Lamiaceae species is more constrained, and thus it is expected that they may be more sensitive to changes in temperature as global warming proceeds.

The type of relationship found between germination response to temperature and altitude suggests that germination in L. pedunculata is favored by warmer temperatures in all populations. Year to year fluctuations in the onset of the wet season will differentially affect the species depending on altitude. While earlier rains (i.e., warmer temperatures) would favor final germination in this species across the whole altitudinal range, later rains (i.e., cooler temperatures) would not do so, the effects being more negative the higher the altitude. We further contend that this species would be favored by climate change, even if the onset of the rainy season was delayed but occurred under warmer temperatures, as might be the case (Giorgi and Lionello 2008). This suggests that this species, which is very abundant in the Iberian Peninsula, might be able to expand towards higher elevations in a context of changing climate since its germination would be favoured by warmer temperatures with altitude. By contrast, T. mastichina is more sensitive to warmer temperatures and would not be favored by factors that would lead to germination under such conditions. Nevertheless, it was also found that final germination in these two species was very high and that, in absolute terms, variations in final germination due to the temperature regimes used, even if significant, were not large (see Fig. 1). Additionally, the germination speed in both species was also high (low $\mathrm{T}_{50}$ ), with more than $50 \%$ of the seeds having germinated in less than a week or so. Since germination is only one of the many processes that affect the demography of species, and given this observed variability in germination, it is difficult to anticipate how effective these variations in sensitivity to temperature will be in ultimately affecting the abundance of these species across their distribution ranges.

Both hard-seeded species were favored by a heat shock, increasing their germination after subjecting them to this treatment, a well known fact for Cistus species (Trabaud and Oustric 1989; Thanos et al. 1992; Valbuena et al. 1992). It is worth noting the differences in the percentage of seeds with a hard coat (i.e., did not germinate without a heat shock) among both Cistus, as well as their different level of stimulation by heat. However, there were no interactions between heat shock and any other variable (altitude or temperature treatment); that is, germination response to the heat shock was similar among treatments and across the range of altitudes tested. Whether different degrees of heating of the seeds during fire would affect these results is not known. Ooi et al. (2012) found a differential sensitivity of hardseeded species to heat pulses simulating a heat wave along an altitudinal gradient. It suggests that the parental environmental in which seeds develop may influence the response thresholds to release physical dormancy. In our case, we simulated a heat shock more similar to that of fire, but did not find any effect with altitude. Cistus species have been shown to respond more to temperatures that occur during fires than to summer temperatures (Moreira and Pausas 2012), and their response thresholds do not appear to be influenced by the temperature environment in which seeds developed at different altitudes, as demonstrated here.

The responses of the Lamiaceae species were variable; $L$. pedunculata was not significantly affected by the heat shock, but $T$. mastichina increased its germination slightly when exposed to heat. Other studies of these species or related taxa support (Luna et al. 2007; Moreira et al. 2010) or contradict (Keeley and Baer-Keeley 1999; Luna et al. 2007; Moreira et al. 2010, 2012) our results. In general, these Lamiaceae 
germinate readily in high numbers, and heat effects, when present, are much less influential than in Cistus species. Thus, while hard-seeded species like Cistus have a rather homogeneous response to heat and the mechanism of action is clearly known (Baskin and Baskin 2000), the effect of heat in the Lamiaceae studied here is variable but relatively insignificant, and the mechanism of action remains to be unveiled.

We demonstrate that germination speed varied among species, being slower in the two Cistus than in both Lamiaceae. The cooler the temperature, as autumn proceeds, the later the germination would occur. It cannot be ruled out that germination speed might be further reduced at temperatures below the lowest tested here. We argue that the four species may be differentially hedging their bets against postgermination risks, the two Lamiaceae germinating very rapidly (i.e., low $\mathrm{T}_{50}$ ) while both Cistus, more so C. salviifolius, delaying germination (i.e., high $\mathrm{T}_{50}$ ). It has been suggested that the earlier the germination the greater the fitness (De Luis et al. 2008). Yet this is not always the case, and first germinates are not necessarily the ones to best survive (Quintana et al. 2004). Thus, not all species are equally atuned to changes in temperature for germinating more or less rapidly. Furthermore, it is also apparent from the changes in $\mathrm{T}_{50}$ induced by heating that time to germination of the Cistus species is not uniform across the genus.

The differential sensitivity of these species to a heat shock here found is consistent with their successional status. Both Lamiaceae are chamaephytes, and are abundant in the early recolonization stages after land abandonment (González Bernáldez 1991). While heat is not required for germination of the Lamiaceae species both tolerate heat and it does slightly increase germination of T. mastichina. In contrast, both Cistus are more dependent on fire though their need of a scarifying agent, such as heat shock, to germinate. Cistus species become more abundant at later stages after abandonment (Ramírez and Díaz 2007; Santana et al. 2011), and they both would benefit from fires of greater intensity, which are more likely to occur as fuel accumulates with time.

Acknowledgments This work was funded by the 7th FP of the European Commission (Project FUME, GA243888) and Ministerio de Ciencia e Innovación of Spain (Project SECCIA, CGL 2006-06914). We thank A. Pardo, L. Díaz and A. Velasco for their technical assistance. Dr. P. Ladd and two anonymous reviewers helped us improve the manuscript.

\section{References}

Akaike H (1992) Information theory and an extension of the maximum likelihood principle. In: Kotz S, Johnson N (eds) Breakthroughs in statistics, vol 1. Springer, London, pp 610-624

Angosto T, Matilla AJ (1993) Variations in seeds of three endemic leguminous species at different altitudes. Physiol Plant 87:329-334

Baskin CC, Baskin JM (1998) Seeds: ecology, biogeography, and evolution of dormancy and germination. Academic Press, San Diego

Baskin CC, Baskin JM (2000) Taxonomy, anatomy and evolution of physical dormancy in seeds. Plant Species Biol 15:139-152

Bell DT, Plummer JA, Taylor SK (1993) Seed germination ecology in southwestern Western Australia. Botan Rev 59:24-73

Cavieres LA, Arroyo MTK (2001) Seed germination response to cold stratification period and thermal regime in Phacelia secunda (Hydrophyllaceae). Altitudinal variation in the Mediterranean Andes of central Chile. Plant Ecol 149:1-8

Céspedes B, Torres I, Urbieta IR, Moreno JM (2012) Effects of changes in the timing and duration of the wet season on the germination of the soil seed bank of a seeder-dominated Mediterranean shrubland. Plant Ecol 213:919-931

Christensen JH, Hewitson B, Busuioc A, Chen A, Gao X, Held R, Jones R, Kolli RK, Kwon WK, Laprise R, Magana Rueda V, Mearns L, Menéndez CG, Räisänen J, Rinke A, Sarr A, Whetton P, Arritt R, Benestad R, Beniston M, Bromwich D, Caya D, Comiso J, de Elia R, Dethloff K (2007) Regional climate projections, Chap. 11. In: Solomon S, Qin D, Manning M, Chen Z, Marquis M, Averyt KB, Tignor M, Miller HL (eds) Climate change 2007: the physical science basis. Contribution of working group I to the fourth assessment report of the intergovernmental panel on climate change. Cambridge University Press, Cambridge, pp 847-940

Cochrane A, Daws MI, Hay FR (2011) Seed-based approach for identifying flora at risk from climate change. Aust Ecol 36:923-935

Corral R, Pita JM, Pérez-García F (1990) Some aspects of seed germination in four species of Cistus L. Seed Sci Technol 18:321-325

De Luis M, Verdú M, Raventós J (2008) Early to rise makes a plant healthy, wealthy and wise. Ecology 89:3061-3071

Donohue K (2002) Germination timing influences natural selection on life-history characters in Arabidopsis thaliana. Ecology 83:1006-1016

Espigares T, Peco B (1993) Mediterranean pasture dynamics: the role of germination. J Veg Sci 4:189-194

Fenner M, Thompson K (2005) The ecology of seeds. Cambridge University Press, Cambridge

Fuentes-Molina N, Estrelles E (2005) Respuesta germinativa de Brassica repanda (Wild.) DC. subsp maritima (Wilk.) Heywood., Lavandula pedunculata (Mill) Cav. y Silene cambessedesii Boiss. and Reut. Anales de Biología 27: 63-68

Galmés J, Medrano H, Flexas J (2006) Germination capacity and temperature dependence in Mediterranean species of 
the Balearic Islands. Investigación Agraria: Sistemas y Recursos Forestales 15:88-95

Gilfedder L, Kirkpatrick JB (1994) Genecological variation in the germination, growth and morphology of four populations of a Tasmanian endangered perennial daisy, Lеисоchrysum albicans. Aust J Bot 42:431-440

Giménez-Benavides L, Milla R (2013) Comparative germination ecology of two altitudinal vicariant Saxifraga species endemic to the north of Spain. Plant Biol 15:593-600

Giorgi F, Lionello P (2008) Climate change projections for the Mediterranean region. Glob Planet Change 63:90-104

González Bernáldez F (1991) Ecological consequences of the abandonment of traditional land use systems in central Spain. In: Baudry J, Bunce RGH (eds) Land abandonment and its role in conservation. Zaragoza: CIHEAM. Options Méditerranéennes: Série A. Séminaires Méditerranéens (15) pp 23-29

International Seed Testing Association (1999) International rules for seed testing. Seed Sci Technol 27: supplement

Kadis C, Kounnamas C, Georghiou K (2010) Seed germination and conservation of endemic, rare, and threatened aromatic plants of Cyprus. Israel J Plant Sci 58:251-261

Keeley JE (1991) Seed germination and life history syndromes in the California chaparral. Bot Rev 57:81-116

Keeley J, Baer-Keeley M (1999) Role of charred wood, heatshock, and light in germination of postfire phrygana species from the Eastern Mediterranean Basin. Israel J Plant Sci 47:11-16

Luna B, Moreno JM (2010) Range-size, local abundance and germination niche-breadth in Mediterranean plants of two life-forms. Plant Ecol 210:85-95

Luna B, Moreno JM, Cruz A, Fernández-González F (2007) Heat-shock and seed germination of a group of Mediterranean plant species growing in a burned area: an approach base on plant functional types. Environ Exp Bot 60:324-333

Luna B, Pérez B, Torres I, Moreno JM (2012) Effects of incubation temperature on seed germination of Mediterranean plants with different geographical distribution ranges. Folia Geobotanica 47:17-27

Mariko S, Koizumi H, Suzuki JI, Furukawa A (1993) Altitudinal variations in germination and growth responses of Reynoutria japonica populations on Mt Fuji to controlled thermal environment. Ecol Res 8:27-34

Matilla A, Gallardo M, Puga-Hermida MI (2005) Structural, physiological and molecular aspects of heterogeneity in seeds: a review. Seed Sci Res 15:63-76

McArthur ED, Meyer SE, Weber DJ (1987) Germination rate at low temperature: rubber rabbitbrush population differences. J Range Manag 40:530-533

Meyer SE, Allen PS (1999) Ecological genetics of seed germination regulation in Bromus tectorum L. I. Phenotypic variance among and within populations. Oecologia 120:27-34

Mondoni A, Probert R, Graziano R, Hay F, Bonomi C (2008) Habitat-correlated seed germination behaviour in populations of wood anemone (Anemone nemorosa L.) from northern Italy. Seed Sci Res 18:213-222

Moreira B, Pausas JG (2012) Tanned or burned: the role of fire in shaping physical seed dormancy. PLoS One 7(12):e51523. doi:10.1371/journal.pone.0051523
Moreira B, Tormo J, Estrelles E, Pausas JG (2010) Disentangling the role of heat and smoke as germination cues in Mediterranean Basin flora. Ann Bot 105:627-635

Moreira B, Tavsanoglu Ç, Pausas JG (2012) Local versus regional intraspecific variability in regeneration traits. Oecologia 168:671-677

Moreno JM, Zuazua E, Pérez B, Luna B, Velasco A, Resco de Dios V (2011) Rainfall patterns after fire differentially affect the recruitment of three Mediterranean shrubs. Biogeosciences 8:3721-3732

Ninyerola M, Pons X, Roure JM (2005) Atlas Climático Digital de la Península Ibérica. Metodología y aplicaciones en bioclimatología y geobotánica. Universidad Autónoma de Barcelona, Bellaterra

Ooi MKJ, Auld TD, Denham AJ (2012) Projected soil temperature increase and seed dormancy response along an altitudinal gradient: implications for seed bank persistence under climate change. Plant Soil 353:289-303

Ortega M, Levassor C, Peco B (1997) Seasonal dynamics of Mediterranean pasture seed banks along environmental gradients. J Biogeogr 24:177-195

Pendleton BK, Meyer SE (2004) Habitat-correlated variation in blackbrush (Coleogyne ramosissima: Rosaceae) seed germination response. J Arid Environ 59:229-243

Pérez-García F (1997) Germination of Cistus ladanifer seeds in relation to parent material. Plant Ecol 133:57-62

Pérez-García F, González-Benito ME (2006) Seed germination of five Helianthemum species: effect of temperature and presowing treatments. J Arid Environ 65:688-693

Pérez-García F, Hornero J, Gozález-Benito ME (2003) Interpopulation variation in seed germination of five Mediterranean Labiatae shrubby species. Israel J Plant Sci 51:117-124

Probert RJ (2000) The role of temperature in the regulation of seed dormancy and germination. In: Fenner T (ed) Seeds: the ecology of regeneration in plant communities, 2nd edn. Cabi Publishing, Oxford, pp 261-292

Quintana JR, Cruz A, Fernández-González F, Moreno JM (2004) Time of germination and establishment success after fire of three obligate seeders in a Mediterranean shrubland of central Spain. J Biogeogr 31:241-249

Ramírez JA, Díaz M (2007) The role of temporal shrub encroachment for the maintenance of Spanish holm oak Quercus ilex dehesas. For Ecol Manage 255:1976-1983

Santana J, Porto M, Reino L, Beja P (2011) Long-term understory recovery after mechanical fuel reduction in Mediterranean cork oak forests. For Ecol Manage 261:447-459

Smith AP (1975) Altitudinal seed ecotypes in the Venezuelan Andes. Am Midl Nat 94:247-250

Thanos CA, Doussi MA (1995) Ecophysiology of seed germination in endemic labiates of Crete. Israel $\mathrm{J}$ Plant Sci 43:227-237

Thanos CA, Georghiou K (1988) Ecophysiology of fire-stimulated seed germination in Cistus incanus ssp. creticus (L.) Heywood and $C$. salviifolius L. Plant, Cell Environ 11:841-849

Thanos CA, Georghiou K, Kadis C, Christina P (1992) Cistaceae: a plant family with hard seeds. Isr J Bot 41:251-263

Thanos CA, Kadis CC, Skarou F (1995) Ecophysiology of germination in the aromatic plants thyme, savory and oregano (Labiatae). Seed Sci Res 5:161-170 
Thompson PA (1970) Germination of species of Caryophyllaceae in relation to their geographical distribution in Europe. Ann Bot 34:427-449

Thurling N (1966) Population differentiation in Australian Cardamine. III. Variation in germination response. Aust $\mathrm{J}$ Bot 14:189-194
Trabaud L, Oustric J (1989) Heat requirement for seed germination of three Cistus species in the garrigue of southern France. Flora 183:250-321

Valbuena L, Tárrega R, Luis E (1992) Influence of heat on seed germination of Cistus laurifolius and Cistus ladanifer. Int $\mathrm{J}$ Widland Fire 2:15-20 